\title{
Avaliação da Atividade Antibacteriana de Enzima Natural em Alicyclobcillus Acidoterrestris
}

Márcia Maria dos Anjos (I), Angela Aparecida da Silva (I), Isabella Carolini Pascoli (I), Jane Graton-Mikcha (I), Jane Graton-Mikcha (I), Miguel Machinski-Júnior (I), Celso Vataru Nakamura (I), Benício Alves de Abreu-Filho (I)

(I) UEM - Universidade Estadual de Maringá ( Avenida Colombo, 5.790, Jardim Universitário, Maringá, Paraná)

\section{Resumo}

O Alicyclobacillus acidoterrestris é um bacilo deteriorante de alimentos acidificados, como sucos cítricos e extratos de tomate. Tem a capacidade de formar esporos, portanto é resistente aos processos térmicos empregados, principalmente em suco de laranja, onde as condições de pasteurização não são suficientes para evitar a sua germinação. O Brasil é um grande produtor e exportador mundial de suco de laranja e alterações na qualidade do suco têm sido relatadas devido a presença deste microorganismo. O uso de proteases exógenas tem sido de grande interesse em diversas áreas, pois estudos demonstram suas propriedades antimicrobianas, antiinflamatórias e antioxidantes entre outras. No entanto, estudos relacionados às bactérias não-patogênicas ou deteriorantes ainda são limitados, principalmente estudos relacionados ao Alicyclobacillus acidoterrestris. Sendo assim, o objetivo deste estudo foi avaliar a ação antibacteriana de uma enzima proteolítica natural: a bromelina (extraída do abacaxi, Ananas comosus) frente ás células vegetativas de Alicyclobacillus acidoterrestris. A metodologia utilizada foi a microdiluição em placa de 96 poços para avaliar a Concentração Inibitória Mínima (CIM), seguida de plaqueamento e incubação para verificar a Concentração Bactericida Mínima (CBM) para cada enzima. Nos ensaios foram utilizados o meio de cultura BAT (ágar e caldo) e a cepa padrão de A. acidoterrestris CBMAI 
0244 ${ }^{\mathrm{T}}$, da Coleção Brasileira de Micro-organismos de Ambiente e Indústria, na concentração padronizada de $10^{5} \mathrm{UFC} / \mathrm{mL}$. Os resultados obtidos foram de $62,5 \mu \mathrm{g} / \mathrm{mL}$ para CIM e $250 \mu \mathrm{g} / \mathrm{mL}$ para CBM. Estes resultados sugerem a utilização deste composto como agente antimicrobiano em sucos naturalmente ácidos, no entanto são necessárias mais pesquisas relacionadas à viabilidade e aplicação deste composto. Instituição de fomento: CAPES.

Palavras-Chave: Alicyclobacillus acidoterrestris, Agente antibacteriano, Protease exógena, Enzima natural

Agência de Fomento: CAPES 